Benha Veterinary Medical Journal
Official Journal Issued by
Faculty of
Veterinary Medicine $\quad$ Journal homepage: https://bvmj.journals.ekb.eg/

Original Paper

\title{
Seroprevalence investigation for viral determined agents of abortion in ewes at El-Menoufia province
}

\author{
Marwa F. Mahmoud ${ }^{1}$, Maha R. Abd El-Fadeel ${ }^{2}$ and Diana M. Abulmagd ${ }^{3}$ \\ ${ }^{1}$ Virology Unit, Reproductive Disease Department, Animal Reproduction Research Institute (ARRI), Giza, Egypt \\ ${ }^{2}$ Rinder pest like diseaseand ${ }^{3}$ Rift Valley Fever Department ${ }^{3}$, Veterinary Serum and Vaccine Research Institute (VSVRI); \\ Abassia, Cairo, Egypt.
}

\begin{tabular}{|c|c|}
\hline ARTICLE INFO & ABSTRACT \\
\hline $\begin{array}{l}\text { Keywords } \\
\text { Abortion } \\
B H V \\
B T V \\
B V D V \\
R V F V \\
\text { Received } 12 / 05 / 2019 \\
\text { Accepted } 19 / 02 / 2019 \\
\text { Availa6le On- } \\
\text { Line } 12 / 05 / 2020\end{array}$ & $\begin{array}{l}\text { Abortions in sheep represent an important cause of the reduction of productivity and the } \\
\text { increase economic losses. There are numerous potential reasons for abortion in ewes, yet } \\
\text { making an authoritative finding is frequently difficult. This investigation identified instances } \\
\text { of abortion among sheep in various areas in El-Menoufia governorate. One hundred and ten } \\
\text { serum samples were collected from } 65 \text { aborted sheep and } 45 \text { in contact one. The samples were } \\
\text { analyzed to determine the suggested viral etiological determinants. The antibodies against of } \\
\text { Bovine Viral Diarrhea Virus (BVDV), Bovine Herpes Virus (BHV), Rift Valley Fever Virus } \\
\text { (RVFV) and Bluetongue Virus (BTV) were detected in the serum samples obtained from } \\
\text { aborted sheep by serum neutralization test (SNT) and indirect enzyme linked immunosorbent } \\
\text { assay (IELISA). The result of SNT showed positive percentage against BVD, BHV, RVF and } \\
\text { BTV as } 14.54 \%, 0.9 \%, 66.36 \% \text { and } 0.9 \% \text {, respectively. While the results of ELISA test was } \\
18.18 \%, 3.63 \%, 77.27 \% \text { and } 2.72 \% \text { for the four viruses, respectively. The results of present } \\
\text { study concluded that the RVF is the main viral cause for abortion in sheep in El-Menoufia } \\
\text { governorate. }\end{array}$ \\
\hline
\end{tabular}

\section{INTRODUCTION}

There are different causes of abortion in sheep representing bacterial, viral, mycotic, parasitic and environmental or even stress factors. As it is well known that there is lack of antiviral treatment, some viruses could be considered the most dangerous causative agent of abortion among ewes.

The most important one is rift valley fever virus (RVFV) which has almost $100 \%$ rate of abortion among pregnant infected females (Pepin et al., 2010). An outbreak of RVF in animals frequently manifests itself as a wave of unexplained abortions among livestock and may signal the start of an epidemic (WHO, 2018). Rift Valley fever (RVF) is caused by a virus that transmitted by mosquitoes after heavy summer rainfall, and it is typically spread along river courses (Hartman, 2017). Infected animals can transmit the disease to others by means of aborted fetuses. RVF is also spread by needles during vaccinations, and this can lead to a mortality rate as high as $95 \%$ amongst young lambs. RVF can lead to an abortion storm in the flock (Pepin et al., 2010).

Many epidemics have been recorded in Egypt during 1977, 1978, 1993 and 2003 (Imam et al., 1979; Arthur et al., 1993; Abd El-Rahim et al., 1999; Samia 2011; Kenawy et al., 2018).

Bluetongue virus infection is a cause of abortion, fetal mummification, stillbirth, and congenital brain malformation in Bovine (Desmecht et al., 2008; Wouda et al., 2009). Bluetongue virus (BTV) has been shown to be abortigenic and teratogenic. After transmission of BTV under natural and experimental conditions, the consequences of vertical transmission in pregnant sheep or cattle are variable. Factors influencing reproductive outcomes are the stage of development, virus characteristics, virus inoculum source and concentration, season, and infection method and path. Reproductive effects vary widely in degree, but usually include miscarriage, abortion, fetal mummification, stillbirth and congenital abnormalities and dysfunctions in the live offspring (Luedke, 1985; Housawi et al., 2004).

A total of 1034 sheep and goat serum samples were obtained and screened for group-specific bluetongue virus antibody using competitive enzyme Linked Immunosorbent Assay (cELISA).Sheep and goat seropositivity for bluetongue was found to be $89.2 \%$. The greater connection between the history of abortion and seropositivity underlines the economic importance of bluetongue virus in the sheep herds of the region( Najarnezhad and Rajae, 2013). Sporadic cases were reported in 2012 with seropositive ruminants (Kawther, 201; Mahmoud and Manal, 2014; Kawther and Wahid, 2015; Ali, 2017). In 2018, new outbreak was recorded on the end of august in Wadi Elnatron, Al Buhayrah, where 35 of 70 cases died and 484 were susceptible with bluetongue virus serotype 4 (OIE, 2019).

\footnotetext{
* Corresponding author: Dr. Marwa F. Mahmoud. Virology Unit, Reproductive Disease Department, Animal Reproduction Research Institute (ARRI), Giza, Egypt
} 
Bovine Viral Diarrhea (BVD) is a viral disease which infects mainly cattle, but can infect sheep, goats, deer and pigs (Hurtado et al., 2003), caused by a pestivirus (similar to the viruses that cause Border Disease in sheep and swine fever in pigs) (O'Neill R.G et al., 2004). Despite a little study on sheep in Egypt, the prevalence of BVDV neutralizing antibodies using the neutralizing peroxidase-linked antibody was $49.2 \%, 52.0 \%, 27.5 \%, 31.4 \%$ and $52.5 \%$ in cattle, buffalo, sheep, goats and camels, respectively (Zaghawa, 1998). A cytopathic bovine viral diarrhea virus (BVDV) was isolated from one of the two kids (Ahmed et al., 2013). A study of antibodies to BVD in South Australian sheep flocks was also studied with results indicating that in the flocks tested, BVD was not common (Evans, 2017).

Despite a little study on sheep in Egypt, BHV-1 detected in serum samples of 1600 small ruminants (sheep and goat) using indirect ELISA technique and showed that the prevalence of BHV-1 reactors were $25.1 \%$ of the total examined animals (Mahmoud and Ahmed, 2009).

Serum Neutralization test is a golden serological test, it detected the antibodies to RVFV with $100 \%$ analytical accuracy and 97\% diagnostic sensitivity(Baratang et al., 2019). ELISA test is a sensitive test and can used in screening (Mahmoud and Ahmed, 2009) it reach 100\% sensitivity and $93.3 \%$ specificity (Zaghawa, 1998).

The main goal of this study is serological investigation to the most viral agents cause abortion in ewes.

\section{MATERIAL AND METHODS}

\subsection{Animals}

The present work was carried out on unvaccinated one hundred ten, 65 native aborted sheep ewes and 45 in contact sheep in 5 different districts (Shebin El-Kom, El Bagour, Menouf, Quesna and Baraka El-Sabe) in El-Menoufia governorate.

\subsection{Samples}

Blood samples were obtained from the aborted ewes and in contact sheep and allowed to form clots at $4^{\circ} \mathrm{C}$ overnight. The serum was separated and centrifuged at $2000 \mathrm{rpm}$ for 15 minutes then kept in sterile screw capped vials at $-20^{\circ} \mathrm{C}$ till subjected for serological examination.

\subsection{Cell culture}

Madine Darby bovine kidney (MDBK) cells and African green monkey kidney (VERO) cell cultures were supplied by Veterinary Serum and Vaccine Research institute (VSVRI). It was used for application of SNT for BVD; BT and IBR and RVF, respectively.

\subsection{Serum Neutralization Test (SNT)}

Two-fold serial dilutions of the sera $(1: 2-1: 128)$ were tested in the presence of 100 TCID $_{50}$ of BTV, ZH501; RVFV, BHV and BVDV with the presence of reference positive control described by Martinelle et al. (2011). The neutralizing antibody titer was expressed as the reciprocal of serum dilution causing a 50\% reduction in the cytopathic effect in Madine-Darby bovine kidney (MDBK) cells and African green monkey kidney (VERO) cells.

\subsection{Indirect Enzyme Linked Immunosorbent Assay (IELISA):}

The antigens of the four viruses were supplied by VSVRI and adsorbed to ELISA plates where the assay was carried out according to Voller et al.(1976). Anti-sheep IgG (whole molecule) peroxidase conjugate antibody developed in donkey with a minimum titer 1:10.000 was obtained from SIGMA $^{\circledR}$ and used in indirect ELISA. The optical density (OD value) of each well was analyzed in the photometer at $450 \mathrm{~nm}$ wavelength. The results based upon the serum samples showing optical density values more than 50 percent of the mean of negative control were taken as positive.

\section{RESULTS}

The obtained SNT results tabulated in table (1) revealed that sixteen samples were considered positive to BVDV where twelve samples have a titer 8 and four samples have a titer 16. Only one serum sample showed positive results for BHV with a titer 16 and only one serum sample has a titer 32 and considered positive for BTV. Seventy-three samples have a titer more than 64 and considered positive for RVFV. Such results came to be confirmed by those of ELISA (Table2) reflecting positive percentage values of $14.54 \%, 0.9 \%$, $66.36 \%$ and $0.9 \%$ for BVD, BHV, RVF and BTV, respectively

Table 1 Serum virus neutralizing antibody titers for BVDV, BHV, BTV and RVFV in aborted and in contact ewes

\begin{tabular}{lccccccc}
\hline Viruses & \multicolumn{7}{c}{ SNT titer } \\
& $<2$ & $2-4$ & 8 & 16 & 32 & $>64$ & Positive percentage \\
\hline BVDV & 84 & 10 & ${ }^{\mathrm{a}} 12$ & ${ }^{\mathrm{a}} 4$ & - & - & $14.54 \%$ \\
BHV & 12 & 86 & 11 & ${ }^{\mathrm{b}} 1$ & - & - & $0.9 \%$ \\
BTV & 10 & 90 & 8 & 1 & ${ }^{\mathrm{c}} 1$ & - & $0.9 \%$ \\
RVFV & 19 & 2 & 1 & 3 & 13 & ${ }^{\mathrm{d}} 73$ & $66.36 \%$ \\
\hline
\end{tabular}

No. of ewes have the protective serum antibody titer $>4$ in BVDV considered positive. bo. of ewes havethe protective serum antibody titer $>10$ in BHV considered positive. ${ }^{\mathrm{c}}$ No. of ewes have the protective serum antibody titer $>20$ in BTV considered positive. ${ }^{d}$ No. of ewes havethe protective serum antibody titer $\geq 40$ in RVFV considered positive.

Table 2 Detection of ewe's serum samples for antibodies against BVD, BHV, RVF and BTV using ELISA

\begin{tabular}{llcl}
\hline $\begin{array}{l}\text { Used virus } \\
\text { antigen }\end{array}$ & $\begin{array}{l}\text { Total serum } \\
\text { number }\end{array}$ & $\begin{array}{l}\text { Number of positive } \\
\text { samples }\end{array}$ & $\begin{array}{l}\text { Positive } \\
\text { percentage }\end{array}$ \\
\hline BVDV & & 20 & $18.18 \%$, \\
BHV & $\uparrow$ & 4 & $3.63 \%$, \\
BTV & 110 & 3 & $2.72 \%$ \\
RVFV & $\downarrow$ & 85 & $77.27 . \%$
\end{tabular}

\section{DISCUSSION}

The present obtained results of SNT (Table1) showed that 12 samples could be considered positive to BVDV with a titer 8 and four samples have a titer 16 with positive percentage $14.54 \%$. In this respect Robert et al. (1995) stated that viral neutralizing antibodies titers less than the detectable are $(<$ $1: 4)$.

Only one serum sample showed positive results for BHV with a titer 16 and only one serum sample had a titer 32 and considered positive for BTV with $0.9 \%$ positivity for both viruses. Viral neutralizing antibodies titers less than the detectable $(<1: 10)$ for BHV-1 (Robert et al., 1995). Serum samples with a titer $>20$ were considered positive for BTV (Martinelle et al., 2011)

On the other side, it seems that RVFV antibodies showed the highest incidence with seventy three samples had a titer more than 64 with positive $(66.36 \%)$ in agreement with the 
fact that serum neutralization test (SNT) can detect antiRVFV antibodies within three days post-infection and diagnostic sensitivity and specificity are $80 \%$ and $97 \%$, respectively as concluded by Baratang et al. (2019), who found that SNT proved suitable for screening sera and plasma for presence of antibodies in viraemic and recovered ewes. In addition, it was stated that the protective antibody titers for RVFV is $(\geq 1: 40)$ against challenge test with RVFV ZH501 strain (Fawzy and Helmy 2019).

Parallel to these findings, ELISA results (Table2) demonstrated positive results for BVD, BHV, BTV and RVF as $20(18.18 \%), 4(3.63 \%), 3(2.72 \%)$ and $85(77.27 \%)$ respectively. Regarding the use of ELISA for detection of the study virus antibodies; many authors applied it, for BVD (Zaghawa, 1998) reported that the sensitivity of the neutralizing peroxidase-linked antibody was $100 \%$, while the specificity was 90.3 for BTV ( Najarnezhad and Rajae, 2013) Ali, (2017) applied Competitive ELISA as a rapid, simple and accurate method for screening of group-specific antibodies against bluetongue virus infection among cattle, sheep and goats for routine monitoring to know the status of bluetongue infection in Egypt.; for BHV-1 Mahmoud and Ahmed (2009)showed that ELISA technique is more sensitive for detection of BoHV-1 antibodies. Baratang et al. (2019) used serum neutralization test to detect anti-RVFV antibodies and showed an analytical specificity of $100 \%$ and diagnostic sensitivity $97 \%$.

The result showed 73 positive samples for RVFV by SNT and 85 positive samples for RVFV by ELISA and they are more than 65 aborted cases (Mohale 2013). The number of cases found to be positive ELISA more than the number of cases found to be positive SNT.

\section{CONCULOSIONS}

We could conclude that obtained results in this investigation, both of SNT and ELISA verified the most prevalent causes of abortion in ewes namely RVFV in El-Menoufia governorate. It could be recommended periodical examination and serosurvying of sheep in this province to the above-mentioned viruses for early diagnosis and design control program to reduce economic losses.

\section{REFERENCES}

1. Abd El-Rahim I.H.A., Abd El-Hakim U . and Hussein M (1999): An epizootic of Rift Valley fever in Egypt in 1997. Rev. sci. tech. Off. int. Epiz., 18 (3), 741-748.

2. Ahmed O. Abdel-layif, Sagar M. Goyal, Yogesh Chander, Ahmed S. Abdel-Moneim, Sabry M. Tamam and Hanafy M. Madbouly(2013): Isolation and molecular characterization of a pestivirus from goats in Egypt. Acta Veterinaria Hungarica 61 (2): 270-280.

3. Ali, W.F. (2017): Competitive ELISA test for detection of bluetongue virus antibodies in cattle, sheep and goats. Animal Health Research Journal 5(1): 39-44.

4. Arthur R.R., S.E. Cope, B.A. Botros, R.G. Hibbs, I.Z.E Imam, R.R. Arthur, M.S. El-Sharkawy, S. Oun, J.C. Morrill, R.E. Shope, and M.A. Darwish,(1993): Recurrence of Rift Valley fever in Egypt. The Lancet journal volume 342(8880): 1149-1150

5. Lubisi B.A., Ndouvhada P.N., Penrith D.M., Sibanda D. Bastos A.D.S. (2019): Evaluation of a virus neutralisation test for detection of rift valley fever antibodies in Suid sera. Trop Med Infect Dis. 4(1): 52-60
6. Evans C (2017): BVD could be "baaa-d" news for sheep and beef farmers, Implemented by Massey University, 2018.https://www.bvdfree.org.nz/node/201

7. Desmecht D, Bergh RV, Sartelet A, Leclerc M, Mignot C Misse F, Sudraud C., Berthemin S., Jolly S., Mousset B., Linden A., Coignoul F., Cassart D. (2008). Evidence for transplacental transmission of the current wild-type strain of bluetongue virus serotype 8 in cattle. Vet Rec.,163:50-52

8. Mohale D. (2013): Abortions and causes of death in newborn sheep and goats. http://webcache.googleusercontent.com/search?q=cache:http: //www.nda.agric.za/docs/Infopaks/abort.pdf.

9. Hartman, A. (2017). Rift Vally fever. Clin Lab Med., 37(2): 285-301.

10. Hurtado, A., García-Pérez, A. L., Aduriz, G., \& Juste, R. A (2003). Genetic diversity of ruminant pestiviruses from Spain. Virus Research, 92(1), 67-73.

11. Housawi F.M.T., Abu Elzein E.M.E., Ramadan R.O., Gameel A.A., Al-Afaleq A.I. and Al-Mousa J. (2004): Abortions, stillbirths and deformities in sheep at the Al-Ahsa oasis in eastern Saudi Arabia: isolation of a bluetongue serogroup virus from the affected lambs. Rev. sci. tech. Off. int. Epiz., 23 (3), 913-920.

12. Imam Z. E. Imam, R. El Karamany, and Medhat A. Darwish (1979): An epidemic of Rift Valley fever in Egypt. Bull World Health Organ; 57(3): 441-443.

13. Kawther S. Zaher (2012): Bluetongue Infection in Small Ruminants in Egypt. Academic Journal of Animal Diseases 1(3): 21-26.

14. Kawther S. Zaher and Wahid M. Ahmed (2015): Observations on the Epidemiology of Bluetongue Disease. Global Veterinaria 14 (6): 800-804.

15. Kenawy MA; Abdel-Hamid YM and Beier JC. (2018): Rift Valley Fever in Egypt an other African countries: Historical review, recent outbreaks and possibility of disease occurrence in Egypt. Acta Tropica., 181: 40-49

16. Luedke AJ (1985): Effect of bluetongue virus on reproduction in sheep and cattle, Prog. Clin. Biol. Res.; 178:71-8.

17. Mahmoud M.A. and S.A. Ahmed (2009): Prevalence of Bovine Herpesvirus-1 in Sheep and Goats in Egypt. Global Veterinaria 3 (6): 472-479.

18. Mahmoud M. A. and Manal H. Khafagi (2014): Seroprevalence of bluetongue in sheep and goats in Egypt. Veterinary World 7(4): 205-208.

19. Martinelle L, Dal Pozzo F, Sarradin P, De Leeuw I, De Clercq K, Thys C, Ziant D, Thiry E and Saegerman C.(2011): Two alternative inocula to reproduce bluetongue virus serotype 8 disease in calves. Vaccine, 27;29(19):3600-3609.

20. Fawzy M., Helmy Y.A. (2019): The One Health Approach is Necessary for the Control of Rift Valley Fever Infections in Egypt: A Comprehensive Review. Viruses, 11(2), 139.

21. OIE (2019): world organization of animal health: Bluetongue in Egypt. https://www.oie.int/wahis_2/public/wahid.php/ Reviewreport/review?page_refer=MapFullEventReport\&rep ortid=29804

22. Pepin M., Bouloy M., Bird B.H., Kemp A., Paweska J. (2010). Rift valley fever virus (Bunyaviridae: Phlebovirus): An update on pathogenesis, molecular epidemiology, vectors, diagnostics and prevention. Vet. Res., 41:61.

23. Robert W. Fulton, A. W. Confer, Lurinda J. Burge, Louis J. Perino, J. M. d'Offay, Mark E. Payton and R. E. Mock (1995): Antibody responses by cattle after vaccination with commercial viral vaccines containing bovine herpesvirus 1 ,bovine viral diarrhea virus, parainfluenza- 3 virus, and bovine respiratory syncytial virus immunogens and subsequent revaccination at day 140. Vaccine13(8), 725-733.

24. Kamal S.A. (2011): Observations on rift valley fever virus and vaccines in Egypt. Virol. J.1, 8: 532-541.

25. Najarnezhad V. Rajae M. (2013): Seroepidemiology of bluetongue disease in small ruminants of north-east of Iran, Asian Pac J Trop Biomed.3(6): 492-495. 
26. O’Neill R.G., O’Connor M., O’Reilly P.J. (2004). A survey of antibodies to pestivirus in sheep in the Republic of Ireland.Irish Vet. J., 57 (9): 525-530.

27. Voller A, Bidwell DE and Bartlett A (1976): Enzyme immunoassays in diagnostic medicine. Theory and practice. Bull World Health Organ; 53(1):55-65.

28. WHO (2018): Rift valley fever. https://www.who.int/newsroom/fact-sheets/detail/rift-valley-fever

29. Wouda W, Peperkamp NH, Roumen MP, Muskens J, van Rijn A, Vellema P. (2009) Epizootic congenital hydranencephaly and abortion in cattle due to bluetongue virus serotype 8 in the Netherlands. Tijdschr Diergeneeskd., 134:422-427. 60 .

30. Zaghawa A. (1998): Prevalence ofhtibodies to Bovine Viral Diarrhoea Virus and/or Border Disease Virus in Domestic Ruminants. J. Vet Med. B 45,345-351. 